\title{
Effects of Silicon Levels and Application Methods on Growth and Quality Characteristics of Narcissus tazetta L.
}

\author{
Ramy Gaber El-Kinany ${ }^{1}$ and Atef MK Nassar ${ }^{2}$ \\ ${ }^{1}$ Department of Horticulture \\ ${ }^{2}$ Plant Protection Department \\ Faculty of Agriculture, Damanhour University, Damanhour, El-Beheira, PO Box 59, Egypt
}

\begin{abstract}
Two pot experiments were carried out during the two successive Winter seasons of 2015/2016 and 2016/2017. The experiments were executed in a private commercial nursery located at Damanhour City, El-Beheira Governorate, Egypt under greenhouse conditions. The objective of this research was to evaluate the effect of silicon (Potassium silicate; $\mathrm{Si}$ ) as a spray, or a soil drench at concentrations of 0,5 and $7.5 \mathrm{mmol}$ in enhancing Narcissus tazetta L. growth, flower production, and quality. The experiment was conducted as a split-plot in a randomized complete block design (RCBD). The obtained results of the two seasons, generally, showed that application of silicon as soil drench at $7.5 \mathrm{mmol}$ recorded the highest mean values of the most data recorded and might be considered as optimal treatment for the production of high yield and quality of narcissus plants under the environmental conditions of Beheira Governorate and other similar regions.
\end{abstract}

Keywords: Potassium silicate, silicon, Narcissus.

\section{INTRODUCTION}

Narcissus, is the most important early-season blooming flowering plant, belongs to the Amaryllidaceae family that includes about 63 species classified into 12 divisions (Hanks, 1993; Dole and Wilkins, 2005). N. tazettais native to the Mediterranean region of Europe and has been acclimatized throughout Europe (Hanks, 2002; Santos-Gally et al., 2011). It's a valuable plant for cosmetics, cut flowers, and landscape plants (Benschop et al., 2010; Hanks, 2002; Steininger, 2010; Sochacki and Orlikowska, 2005). N. tazetta flowers have a pleasant and very strong scent, so it is highly valued in the fragrance industry (Van Dort et al., 1993; Chen et al., 2013).

The growth and flower quality of narcissus could be improved by adopting proper cultural practices, application of plant nutrients such as silicon ( $\mathrm{Si}$ ), which plays a vital role in the quality of flowers. In this concern, Khenizy and Ibrahim (2015) mentioned that $\mathrm{Si}$ is one of the most important nutrients influencing growth and yield in gladiolus by increasing shoot and flower growth parameters. Also, $\mathrm{Si}$ is a growth promoter of various higher plant species (Epstein, 1999 and Zhao et al., 2013). It stimulates growth either indirectly by the accumulation of the $\mathrm{Si}$ in the epidermal tissue of the plant, which provides defense against insect and fungal attacks and alleviates biotic and abiotic stresses, or directly by originating both morphological changes and physiological processes in plants.

Silicon is not yet classified as an essential nutrient for most plants (Epstein 1994and 1999). It is considered the second most abundant element in the earth's crustnext to oxygen, with soils containing approximately $32 \%$ by weight (Lindsay, 1979;
Wedepohl, 1995; Liang et al., 2006). Several studies suggested that silicon has several beneficial effects on different aspects of the plant growth such as stimulation of photosynthesis, reduction of transpiration, crop quality, enhancement of plant resistance to abiotic and biotic stresses and postharvest quality parameters (Epstein, 1994; Hodson and Sangster, 1999; Liang et al., 2001; ; Seebold et al., 2001; Ma and Takahashi, 2002 and Zhou et al., 2002).

Mechanistically, $\mathrm{Si}$ is absorbed by plants in silicic acid form where it is transported to the shoot in concentrations ranging from 0.1 to $0.6 \mathrm{mmol}$ in the soil (Epstein, 1994). After the loss of water, it is polymerized as silica gel on stems surface and leaves surface and blade, which keep the leaf erect, thereby improving light-capturing by leaves and stimulating canopy photosynthesis (Ma and Takahashi, 2002).

Also, the concentrations range of silicon in different plants from $0.1 \%$ (similar to $\mathrm{P}$ and $\mathrm{S}$ ) to more than $10 \%$ of whole plant dry matter (Epstein, 1999, Kamenidou et al., 2009). One of the most important facts is that silicon in the soil helps plants survive in the bad conditions like water shortage and drought by decreasing transpiration in cells with higher silicon concentration (Gao et al., 2006). All of these may influence plant development, for example, shoot growth, flowering quality and longevity and fruit production. (Jana and Jeong, 2014; Wróblewska and Dębicz, 2011). Therefore, the objectives of the current study were to a) evaluate silicon (as Potassium Silicate) as an enhancer of Narcissustazetta crop and flower quality and b) compare the best application method as a spray or drench. 


\section{MATERIALS AND METHODS}

Two pot experiments were carried out during the two successive winter growing seasons of 2015/2016 and 2016/2017. The experiments were executed in a private commercial nursery located at Damanhour City, in Beheira Governorate, Egypt under greenhouse conditions. Uniform bulbs of paperwhite Narcissustazettacv. "Ziva" $13-15 \mathrm{~cm}$ circumference, were obtained from Orman Botanical Garden, Giza, Egypt. This variety was chosen because of its fame. It usually has three to twenty flowers on a stout stem with perianth segments spreading not reflexed and flowers. Bulbs were grown on 20 October of both seasons in $25 \mathrm{~cm}$ black plastic pots filled with sandy soil. Soil samples were collected and physical and chemically analyzed according to the published procedures of Black et al. (1965).

Table 1: Physical and chemical analyses of soil samples of the experiment.

\begin{tabular}{lcc}
\hline Physical analysis & Firstseason & Secondseason \\
\hline Clay $(\%)$ & 0.77 & 0.72 \\
\hline Silt $(\%)$ & 7 & 8.03 \\
\hline Sand $(\%)$ & 92.23 & 91.25 \\
\hline Texture class & sand & sand \\
\hline Chemical analysis & & \\
\hline $\mathrm{EC}(\mathrm{dS} / \mathrm{m})$ & 0.8 & 0.87 \\
\hline $\mathrm{pH}$ & 7.9 & 7.8 \\
\hline $\mathrm{Ca}(\mathrm{meq} / \mathrm{L})$ & 20.1 & 20.52 \\
\hline $\mathrm{Mg}(\mathrm{meq} / \mathrm{L})$ & 6.23 & 6.98 \\
\hline $\mathrm{SO}{ }_{4}(\mathrm{meq} / \mathrm{L})$ & 8.21 & 7.98 \\
\hline $\mathrm{K}(\mathrm{meq} / \mathrm{L})$ & 5.23 & 5.35 \\
\hline \multicolumn{1}{c}{$\mathrm{A})$} &
\end{tabular}

After 60 days of planting, bulbs were treated with silicon (potassium silicate) concentrations as a foliar spray or soil drench at the rates of 0,5 , and $7.5 \mathrm{mmol}$. Bulbs were divided into two equal groups. the first group was specified for the foliar spray and the second one was specified for soil drench treatments.

Silicon aqueous solutions were applied as foliar spray and soil drench 4 times at the concentrations of 0 (tap water) 5 and $7.5 \mathrm{mmol}$. The two application methods (spray or soil drench) were firstly applied after 67 days from planting. The second, third and fourth applications were after 74, 81 and 88 days of planting, respectively. For the foliar spray, the pot surface was covered with polyethylene before application to avoid falling of spray drips on the growing medium. All concentrations were applied using a hand sprayer and non-ionic surfactant tween 80 at $0.05 \%(\mathrm{v} / \mathrm{v})$ was added to all treatments to reduce the surface tension and increase the contact angle of sprayed droplets. Each plant was sprayed individually, so that, all foliage was moistened until the point of runoff. The spraying volume was $15 \mathrm{ml}$. per plant. Considering the soil drench, no watering was applied for two days before the application. The drench volume was $450 \mathrm{ml}$ per pot. Two days after chemical application, plants didn't receive any irrigation.

All plants were fertilized with the same rates of $\mathrm{N}, \mathrm{P}$ and $\mathrm{K}$ fertilization. All other cultural practices were adapted whenever they were necessary and as commonly recommended in the commercial production of narcissus. Irrigation was done as needed.A week after last treatment the following characteristics were recorded:

\section{Vegetative growth characters}

Three random plants were chosen and the vegetative growth traits namely; number of leaves per plant, leaf length, leaf area $\left(\mathrm{cm}^{2}\right)$ according to Zidan (1962), leaves fresh weight (g), leaves dry weight per plant $(\mathrm{g})$ were measured without the inflorescences and bulbs at the end of the experiment for all plants. Dry weight measurements were done by drying the plant samples in the oven at $70{ }^{\circ} \mathrm{C}$ for 72 hours to a constant weight then left to cool inside the oven and weighed in grams. In all cases, the weight measurements were performed using a digital scale with a precision of 0.001 digits.

\section{Bulbs characters}

Bulb size $\left(\mathrm{cm}^{3}\right)$ according to a modified method of AOAC Official Method (2000). Exactly, bulbs were poured into a $500 \mathrm{ml}$ beaker with $300 \mathrm{ml}$ of water without immersing the bulbs. The vertical levels of water in the beaker were reported before and after the addition of bulbs. Then the difference was used to calculate the volume of bulbs in $\mathrm{cm}^{3}$. The size measurements were repeated 5 times.Also, bulbs fresh weight/plant (g), and bulbs dry weight/plant (g) were measured. Dry weight measurements were done as described in the previous section.

\section{Flowering growth characters}

Flowering date (expressed as the mean number of days from planting to first open flower for each plant in each treatment per replicate), number of flowers per inflorescense, flower diameter $(\mathrm{cm})$, flowering duration (day), longevity of flower (numer of days from the buds oppenig to the wilt of flowers), flower fresh weight (g; all fully opened flowers per plant at the beginning of fading stage were used), flower dry weight (g), scape length $(\mathrm{cm})$, scape fresh weight $(\mathrm{g})$ and scape dry weight (g).

\section{Chemical analyses}

Chlorophyll a, b and total carotenoid contents $(\mu \mathrm{g} / \mathbf{m L})$ were measured spectrophotometrically according to (Lichtenthaler and Buschmann, 2001).

Silicon content in leaves, bulbs, and flowers $(\mu \mathrm{g} / \mathrm{g})$ was measured according to a modified extraction procedure described by Novozamsky et al. (1984). For silicon analysis a spectrophotometric method for determining gross silicon amounts from either tissue 
or aqueous solution. Adapted from (Elliott and Snyder, 1991; Taber et al., 2002).

\section{Statistical Analysis}

The experiments were conducted as a split plots system in a randomized complete blocks design (RCBD) with three replications (Snedecor and Cochran, 1967). The application methods (spray or soil drench) were arranged as the main plots, and the silicon concentrations were considered as subplots. Each treatment consisted of three pots. Data were analyzed by Statistical Analysis Systems (CoStat, 2008) and the means were compared by Tukey multiple comparison post-hoctest at 0.05 probability.

\section{RESULTS AND DISCUSSIONS}

\section{Vegetative growth characters:}

The data showing the main effects of the two studied factors ("spray and soil drench" and different levels of silicon) and their interactions on vegetative growth of narcissus plants during the two growing seasons of 2015/2016 and 2016/2017were presented in Table(2).

Regarding the main effect of application methods "spray and soil drench" on vegetative growth parameters, data in Table (2) indicated that soil drench showed significant difference and higher mean values of leaf length, leaf area and leaves fresh weight in both seasons and numbers of leaves per plant in the second season than that of spray method. However, there was no significant difference between the two application methods in leaves dry weight in both seasons and numbers of leaves per plant in the first season only.

Soil drench application gave better results than foliar spray one in most of the studied cases of vegetative growth of both seasons. This may be attributed to that after the absorption of the silicon element available in the soil solution, this element moves through the flow of water transpiration in the xylem to the aerial part and stabilize on the epidermal tissues as silica (Ma and Yamaji, 2006). The layer of silica that settled on the plant strengthens the plants cell wall, making the leaves more straight. Consequently, there is an increase in light interception, which causes an optimization of the photosynthetic apparatus (Tamai and Ma, 2008 and Isa et al., 2010). Moreover, the beneficial effects of silicon may also be attributed to the amelioration in the water use efficiency and to the cell elongation, which, promoting the plant's growth and consequently, the increase of biomass (Hossain et al., 2002; Isa et al., 2010).

The aforementioned results are in good accordance with those postulated by Ahmad et al. (2013), Gonzalez-Peres et al. (2014) and Khenizy and Ibrahim (2015) on gladiolus, Mirabbasi et al. (2013) on Asiatic lily plant and Zaky (2014) on calla lily.
Concerning the main effect of different rates of silicon on vegetative growth parameters, data in Table (2) indicated that, as silicon levels increased the given vegetative growth parameters i.e.leaf length, leaf area, leaves fresh weight and leaves dry weight increased significantly during both seasons compared to the control treatments. However, the difference between silicon at $5 \mathrm{mmol}$ and control treatment was not affected in leaves dry weight in the first season only. Results, also, showed that there was no significant difference between the two silicon concentrations (5 and $7.5 \mathrm{mmol}$ ) in the numbers of leaves per plant and leaves fresh weight in both seasons. The highest values of leaf length, leaf area and leaves dry weight were obtained from silicon level at 7.5 mmolin both seasons. At 7.5 mmol silicon level, the estimated percentages increase in leaf length, leaf area, leaves fresh weight and leaves dry weight were (36.05 and $40.72 \%$ ), (61.24 and 58.42\%), (30.17 and $27.47 \%$ ), and (74.85 and 84.54 compared to the control treatment for the first and second season, respectively.

Generally, the superior influence of $\mathrm{Si}$ treatments on stimulating the vegetative growth parameters may be due to enhancing the uptake and transport of water and minerals in xylem sap, increasing antioxidant activity, the concentration of IAA hormone and improving the function of the photosynthetic apparatus and photo-assimilate translocation (Lu et al., 2002; Le et al., 2014 and Janmohammadi et al., 2017), thus leading to augmentation of plant growth parameters. The increasing of leaf length and leaf area in treating plants with silicon suggest that in addition to benefits of $\mathrm{Si}$ in increasing cell turgor by keeping water, Si could be involved in cell wall metabolism improving the ability of the cell wall to expand and consequently enhancing cell enlargement (RomeroAranda et al., 2006). The increases in numbers of leaves per plant due to silicon may be attributed to its role in improving morphological, anatomical and physiological characteristics of leaves (Sivanesan and Park, 2014) and, it's an important role in improving plant water status and adequate supply of nutrients (Romero-Aranda et al., 2006) and its indirect effects such as increased capacity and efficiency of photosynthesis and transpiration (Korndörfer et al., 2004 and Liang, 2003). Increasing the leaf length, leaf area and numbers of leaves per plant leads to increase in leaves fresh and dry weight

Results of leaf length seemed to agree with those reported by Ahmad et al. (2013), Gonzalez-Peres et al. (2014) and Khenizy and Ibrahim (2015) on gladiolus, Shanan and El Sadek (2017) on tuberose plants and Zaky (2014) on calla lily. 
Table 2: Effects of silicon concentrations (0, 5 and $7.5 \mathrm{mmol})$ and its application method $(\mathrm{S}=$ foliar spray, $\mathrm{D}=$ soil drench) on the vegetative characteristics of $N$. tazetta plants during both seasons.

\begin{tabular}{|c|c|c|c|c|c|c|c|c|c|c|c|}
\hline \multirow{2}{*}{\multicolumn{2}{|c|}{ Treatments }} & \multicolumn{2}{|c|}{$\begin{array}{c}\text { Number of leaves } \\
\text { per plant }\end{array}$} & \multicolumn{2}{|c|}{ leaf length $(\mathrm{cm})$} & \multicolumn{2}{|c|}{ Leaf area $\left(\mathrm{cm}^{2}\right)$} & \multicolumn{2}{|c|}{ LFW (g) } & \multicolumn{2}{|c|}{ LDW (g) } \\
\hline & & $1^{\text {st }}$ & $2^{\text {nd }}$ & $1^{\text {st }}$ & $2^{\text {nd }}$ & $1^{\text {st }}$ & $2^{\text {nd }}$ & $1^{\text {st }}$ & $2^{\text {nd }}$ & $1^{\mathrm{st}}$ & $2^{\text {nd }}$ \\
\hline \multirow[t]{3}{*}{$\mathrm{D}$} & & $10.78 \mathrm{~A}$ & $10.33 \mathrm{~A}$ & $24.11 \mathrm{~A}$ & $23.56 \mathrm{~A}$ & $27.33 \mathrm{~A}$ & $27.33 \mathrm{~A}$ & $36.22 \mathrm{~A}$ & $34.78 \mathrm{~A}$ & $4.48 \mathrm{~A}$ & $4.32 \mathrm{~A}$ \\
\hline & 0 & $7.17 \mathrm{~B}$ & $7.00 \mathrm{~B}$ & $18.50 \mathrm{C}$ & $18.00 \mathrm{C}$ & $18.50 \mathrm{C}$ & $18.83 \mathrm{C}$ & $28.17 \mathrm{~B}$ & $28.50 \mathrm{~B}$ & $3.38 \mathrm{~B}$ & $3.17 \mathrm{C}$ \\
\hline & 7.5 & $10.33 \mathrm{~A}$ & $10.67 \mathrm{~A}$ & $25.17 \mathrm{~A}$ & $25.33 \mathrm{~A}$ & $29.83 \mathrm{~A}$ & $29.83 \mathrm{~A}$ & $36.67 \mathrm{~A}$ & $36.33 \mathrm{~A}$ & $5.91 \mathrm{~A}$ & $5.85 \mathrm{~A}$ \\
\hline \multirow{3}{*}{$\mathrm{S}$} & 0 & $7.00 \mathrm{~b}$ & $7.33 \mathrm{~b}$ & $17.33 \mathrm{e}$ & $17.67 \mathrm{e}$ & $18.00 \mathrm{e}$ & $18.67 \mathrm{~d}$ & $27.00 \mathrm{c}$ & $28.67 \mathrm{c}$ & $3.03 \mathrm{~d}$ & $3.17 \mathrm{c}$ \\
\hline & 5 & $9.00 \mathrm{~b}$ & $9.33 \mathrm{ab}$ & $19.33 \mathrm{~d}$ & $20.67 \mathrm{~d}$ & $22.67 \mathrm{~d}$ & $23.33 \mathrm{c}$ & $32.33 b c$ & $32.67 \mathrm{bc}$ & $4.10 \mathrm{c}$ & $4.11 \mathrm{bc}$ \\
\hline & 7.5 & $8.00 \mathrm{~b}$ & $9.33 \mathrm{ab}$ & $22.00 \mathrm{c}$ & $23.67 \mathrm{c}$ & $26.33 \mathrm{c}$ & $25.67 \mathrm{bc}$ & $33.00 \mathrm{bc}$ & $34.33 \mathrm{ab}$ & $6.51 \mathrm{a}$ & $6.24 \mathrm{a}$ \\
\hline $\mathrm{D}$ & 0 & $7.33 \mathrm{~b}$ & $6.67 \mathrm{~b}$ & $19.67 \mathrm{~d}$ & $18.33 \mathrm{e}$ & $19.00 \mathrm{e}$ & $19.00 \mathrm{~d}$ & $29.33 \mathrm{c}$ & $28.33 \mathrm{c}$ & $3.73 \mathrm{~cd}$ & $3.17 \mathrm{c}$ \\
\hline
\end{tabular}

$\overline{1^{\text {st }}}$ and $\overline{2^{\text {nd }} \text {; first season and second }} \overline{\text { season. Means were compared using Tukey's Honest Significant Difference test }}$ $(P \leq 0.05) ; \mathrm{n}=3$; Means with the same small letter show no significant interaction between different concentrations and application method of $\mathrm{Si}$ and means with the same capital letters are no significantly different between application methods.

Results of leaf area are in good accordance with those postulated by Helaly and El-Hoseiny (2017) on Banana and Khenizy and Ibrahim (2015) on gladiolus. Results of the numbers of leaves per plant are in harmony with those reported by Bazaraa (2018) on Freesia refracta cv. Red Lion and Shanan and El Sadek (2017) on tuberose. And the results of leaves fresh and dry weight are in good accordance with those postulated by Khenizy and Ibrahim (2015) on gladiolus and Shanan and El Sadek (2017) on tuberose.

The interaction effects between the application methods "spray or soil drench" and silicon levels on vegetative growth characters were significant in both seasons (Table 2). The combined treatment of soil drench and silicon at $7.5 \mathrm{mmol}$ recorded the highest mean values for number of leaves per plant, leaf length, leaf area and leaf fresh weight in both seasons. On the other hand, the highest mean value of leaves dry weight was achieved when sprayed silicon at $7.5 \mathrm{mmol}$. The present results are in parallel with those reported by Khenizy and Ibrahim (2015) on gladiolus.

\section{Bulbs characters:}

In terms of the main effect of application methods "spray or soil drench" on bulb characters, data in Table (3) exhibited clearly that the application method of soil drench exposed significant difference and gave higher mean values of bulb size, number of bulbs per plant, in the first season and bulbs fresh weight in second season than the foliar spray. On the other hand, there was no significant difference between the two application methods on bulb size' number of bulbs per plant in the second season, bulbs fresh weight in the first season and bulbs dry weight in both seasons. The present results are in agreement with those obtained by several authors; Ahmad et al. (2013), GonzalezPeres et al. (2014) and Khenizy and Ibrahim (2015) on gladiolus.

Regarding the main effect of different rates of silicon on bulbs parameters, data in Table (3) indicated that the application of silicon significantly enhanced bulb size, number of bulbs per plant, bulbs fresh weight and bulbs dry weight of $N$. tazetta plants compared to the control treatment in both seasons. Irrespective of bulb size at $7.5 \mathrm{mmol} \mathrm{Si}$ in the first season, there were no significant differences between the two concentrations 5 and $7.5 \mathrm{mmol}$ of silicon in the other bulb characters in both seasons. The increasing of bulb size and number of bulbs per plant in treating plants with silicon may be attributed to the role of $\mathrm{Si}$ on promoting the synthesis of more assimilates stored in the new bulbs and make them relatively greater and heavier and the benefits of $\mathrm{Si}$ in increasing cell turgor by keeping water, Si could be involved in cell wall metabolism improving the ability of the cell wall to expand and consequently enhancing cell enlargement (Romero-Aranda et al., 2006). The increasing of bulbs fresh and dry weight per plant may be due to the role of $\mathrm{Si}$ on promoting the synthesis of more assimilates stored in the new bulbs and make them relatively greater and heavier. On the same line, those results detected by Gonzalez-Peres et al., (2014) and Khenizy and Ibrahim (2015) on gladiolus and Bazaraa (2018) on Freesia refracta cv. Red Lion. 
Table 3: Effects of silicon concentrations (0, 5 and $7.5 \mathrm{mmol})$ and its application method $(\mathrm{S}=$ foliar spray, $\mathrm{D}=$ soil drench) on the bulb characteristicsof $N$. tazetta plants during both seasons.

\begin{tabular}{|c|c|c|c|c|c|c|c|c|c|}
\hline \multirow{2}{*}{\multicolumn{2}{|c|}{ Treatments }} & \multicolumn{2}{|c|}{$\begin{array}{c}\text { Bulb size } \\
\left(\mathrm{cm}^{3}\right)\end{array}$} & \multicolumn{2}{|c|}{$\begin{array}{c}\text { Number of bulbs } \\
\text { per plant }\end{array}$} & \multicolumn{2}{|c|}{$\begin{array}{c}\text { Bulbs fresh weight } \\
\text { (g) }\end{array}$} & \multicolumn{2}{|c|}{$\begin{array}{c}\text { Bulbs dry weight } \\
\text { (g) }\end{array}$} \\
\hline & & $1^{\mathrm{st}}$ & $2^{\text {nd }}$ & $1^{\mathrm{st}}$ & $2^{\text {nd }}$ & $1^{\text {st }}$ & $2^{\text {nd }}$ & $1^{\mathrm{st}}$ & $2^{\text {nd }}$ \\
\hline$S$ & & $20.11 \mathrm{~B}$ & $20.89 \mathrm{~A}$ & $3.22 \mathrm{~B}$ & $3.00 \mathrm{~A}$ & $78.67 \mathrm{~A}$ & $82.67 \mathrm{~B}$ & $13.66 \mathrm{~A}$ & $13.96 \mathrm{~A}$ \\
\hline \multirow[t]{4}{*}{$\mathrm{D}$} & & $21.78 \mathrm{~A}$ & $21.56 \mathrm{~A}$ & $3.78 \mathrm{~A}$ & $3.56 \mathrm{~A}$ & $83.89 \mathrm{~A}$ & $85.67 \mathrm{~A}$ & $15.04 \mathrm{~A}$ & $14.96 \mathrm{~A}$ \\
\hline & 0 & $16.17 \mathrm{C}$ & $17.33 \mathrm{~B}$ & $2.33 \mathrm{~B}$ & $2.00 \mathrm{~B}$ & $62.50 \mathrm{~B}$ & $70.67 \mathrm{~B}$ & $11.48 \mathrm{~B}$ & $12.06 \mathrm{~B}$ \\
\hline & 5 & $22.17 \mathrm{~B}$ & $22.33 \mathrm{~A}$ & $4.00 \mathrm{~A}$ & $3.83 \mathrm{~A}$ & $88.33 \mathrm{~A}$ & $90.33 \mathrm{~A}$ & $15.38 \mathrm{~A}$ & $14.76 \mathrm{~A}$ \\
\hline & 7.5 & $24.50 \mathrm{~A}$ & $24.00 \mathrm{~A}$ & $4.17 \mathrm{~A}$ & $4.00 \mathrm{~A}$ & $93.00 \mathrm{~A}$ & $91.50 \mathrm{~A}$ & $16.19 \mathrm{~A}$ & $16.56 \mathrm{~A}$ \\
\hline \multirow{3}{*}{$\mathrm{S}$} & 0 & $16.33 \mathrm{~d}$ & $18.00 \mathrm{c}$ & $2.33 \mathrm{~b}$ & $2.00 \mathrm{a}$ & $61.00 \mathrm{~b}$ & $71.67 \mathrm{c}$ & $11.23 \mathrm{c}$ & $11.91 \mathrm{~b}$ \\
\hline & 5 & $20.67 \mathrm{c}$ & $21.00 \mathrm{~b}$ & $3.67 \mathrm{ab}$ & $3.33 \mathrm{a}$ & $86.67 \mathrm{a}$ & $88.33 \mathrm{~b}$ & $14.01 \mathrm{~b}$ & $14.28 \mathrm{ab}$ \\
\hline & 7.5 & $23.33 \mathrm{~b}$ & $23.67 \mathrm{ab}$ & $3.67 \mathrm{ab}$ & $3.67 \mathrm{a}$ & $88.33 \mathrm{a}$ & $88.00 \mathrm{~b}$ & $15.74 \mathrm{ab}$ & $15.70 \mathrm{ab}$ \\
\hline \multirow{3}{*}{$\mathrm{D}$} & 0 & $16.00 \mathrm{~d}$ & $16.67 \mathrm{c}$ & $2.33 \mathrm{~b}$ & $2.00 \mathrm{a}$ & $64.00 \mathrm{~b}$ & $69.67 \mathrm{c}$ & $11.73 \mathrm{c}$ & $12.21 \mathrm{~b}$ \\
\hline & 5 & $23.67 \mathrm{ab}$ & $23.67 \mathrm{ab}$ & $4.33 \mathrm{ab}$ & $4.33 \mathrm{a}$ & $90.00 \mathrm{a}$ & $92.33 \mathrm{ab}$ & $16.75 \mathrm{a}$ & $15.24 \mathrm{ab}$ \\
\hline & 7.5 & $25.67 \mathrm{a}$ & $24.33 \mathrm{a}$ & $4.67 \mathrm{a}$ & $4.33 \mathrm{a}$ & $97.67 \mathrm{a}$ & $95.00 \mathrm{a}$ & $16.64 \mathrm{a}$ & $17.42 \mathrm{a}$ \\
\hline
\end{tabular}

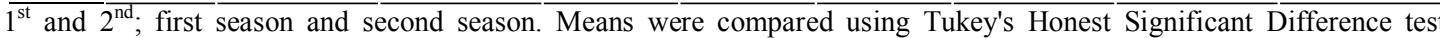
$(P \leq 0.05) ; \mathrm{n}=3$; Means with the same small letter show no significant interaction between different concentrations and application method of $\mathrm{Si}$ and means with the same capital letters are no significantly different between application methods.

The effect of interaction between the application methods "spray or soil drench" and silicon levels on bulb characters were significant in both seasons (Table3). The statistical analysis revealed that the highest mean values of bulb size, number of bulbs per plant, bulbs fresh weight and bulbs dry weight of $N$. tazettawere achieved when plants received 7.5 mmol silicon as soil drenchin both seasons. At 7.5 mmol silicon level, the estimated percentages increase in bulb size, number of bulbs per plant, bulbs fresh weight and bulbs dry weight were (51.52 and 38.49\%), (78.97 and 100\%), (48.8 and $29.48 \%$ ), and (41.03 and 37.31compared to the control treatment for the first and second season, respectively. The present results were in parallel with those reported by Ahmad et al. (2013), Gonzalez-Peres et al. (2014) and Khenizy and Ibrahim (2015) on gladiolus.

\section{Flower characteristics:}

Concerning the main effect of application methods "spray or soil drench" on flower parameters, the obtaind results presented in Table (4) showed that the two application methods of silicon significantly affected flower characters. Spray application gave the longest flowering period in both seasons. However, the drench method gave the highest mean value of flower longevity, flower fresh weight, flower dry weight, scape length, scape fresh weight in both seasons and scape dry weight in the first season only. In addition, the two application methodsincreased the flowering duration, flower diameter and flowers number per inflorescens in both seasons compared to control while, scape dry weight was increased in the second season only. There were no significant differences between the application methods on flowering duration, flower diameter, flowers number per inflorescens, and flower scape. Current findings were in agreement with the results of Bayat and Aminifard (2018) on Narcissus tazetta L. cv. 'Shahla'.

Pertaining the main effect of different rates of silicon on flowers parameters, data in Table (4) indicated that application of silicon significantly increased flowering duration, flower diameter, flower longevity, flowers number per inflorescens, flower fresh and dry weight, scape length, scape fresh weight, scape dry weight, while the number of days to flowering was decreased compared to control treatments in both seasons. Results, also, indicated that there were insignificant differences between the two silicon concentrations (5.0 and 7.5 $\mathrm{mmol}$ ) with the exception of flower duration in both seasons and number of days to flowering and flower diameter in the second season only.

Improving the flower longevity and increasing number of the flowers per inflorescens by using $\mathrm{Si}$ could be explained through the role of $\mathrm{Si}$ in improving water balance and increasing chlorophyll content and more photosynthesis resulted in increasing carbohydrates content in stem and leaves which consequently increased the vase life (Ma and Takahashi, 2002) and flowers number. Moreover, silicon provides the plants with macro- and micronutrients necessary for best growth and high quality (Epstein, 1994).

The aforementioned results of flower longevity are similar to those of Carvalho et al., (2013) on Dendrobium nobile orchid and Babalar et al., (2016) on gerbera. And, the obtained data of number of the flowers per inflorescens were in agreement with those obtained by Khenizy and Ibrahim (2015) on gladiolus, Roohizadeh et al. (2015) on Vicia faba L., and Bazaraa (2018) on Freesia refracta cv. Red Lion. 


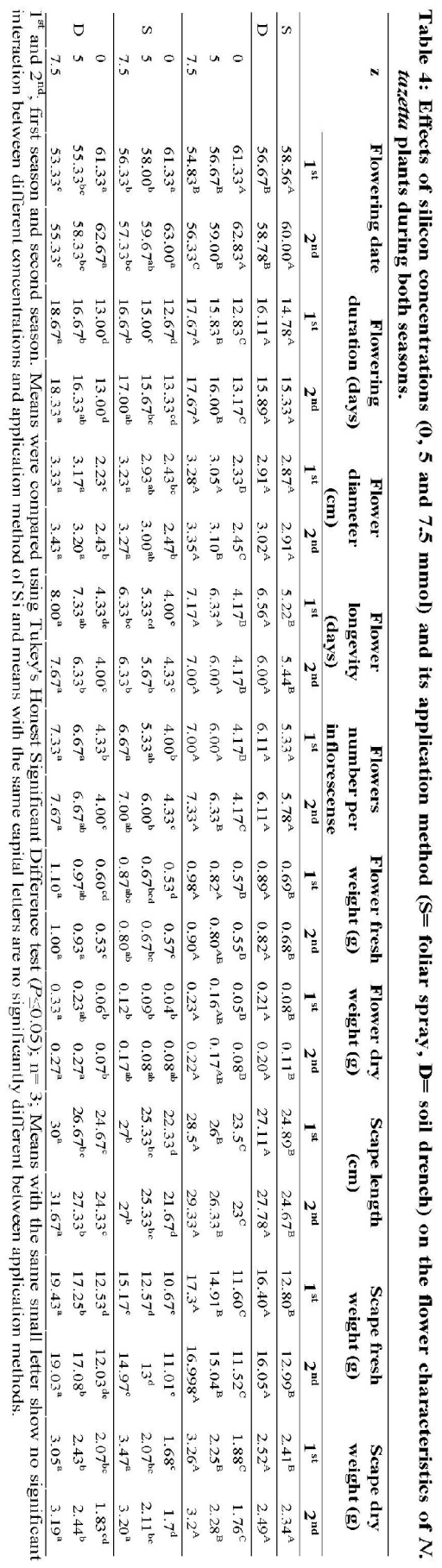


The increase of flowering duration as a result of $\mathrm{Si}$ treatment might be due to the increase of number of flowers per plant and the increases of vase life of the flower on the plan. Results of the duration of flowering are in harmony with the findings of Carvalho et al. (2013) on Dendrobium nobile orchid and Roohizadeh et al. (2015) on Vicia faba L.

The increases of flower diameter and flower fresh and dry weight might be due to the role of silicon in reducing evapotranspiration ( $\mathrm{Lu}$ and Cao, 2001; McAvoy and Bernard, 1996), which could have contributed to increase turgor pressure within the flower, resulting in cell swelling and thus larger flower diameters, which lead to increasing flower fresh and dry weight. Also, silicon encourages the photosynthetic apparatus by promoting the chlorophyll contents, as well as positively impact on the water balance (Rubinowska et al., 2014), which altogether results in the increase of the photosynthetic activity of leaves which supplies flower structures with organic compounds (primarily carbohydrates) and thus larger flower size which lead to increasing flower fresh and dry weight. As primarily carbohydrates are being used to flower growth and/or production of floral reward.

The obtained results of flower diameter are in good accordance with those postulated by Zaky (2013) on rose cv. 'grand prix' and Aghajani and Jafarpour (2016) on gerbera. The results of flower fresh and dry weight per plant seemed to agree with those reported by Amin et al., (2016) on maize and Bayat and Aminifard (2018) on Narcissus tazetta L. cv. 'Shahla'.

The increased scape length might be attributed to the benefits of $\mathrm{Si}$ in increasing cell turgor by keeping water. Additionally, Si was reported to be involved in cell wall metabolism through the improvement cell wall ability to expand and consequently enhance cell enlargement (RomeroAranda et al., 2006). Moreover, the beneficial effects of silicon might be attributed to the amelioration of water use efficiency and cell elongation, which promote the plant's growth and consequently, the increase of biomass (Hossain et al., 2002; Isa et al., 2010). The increase inscape fresh and dry weight might be due to the increased of scape length and the fresh and dry weight of flowers as a result of the silicon application. These results were supported by findings of Khenizy and Ibrahim (2015) and Carvalho-Zanão et al. (2017) on gladiolus, Shanan and El Sadek (2017) on tuberose, and Bazaraa (2018) on Freesia refracta cv. Red Lion.

The decreases in the number of days to flowering due to silicon might be to the role of silicon in the uptake, translocation, and availability of other nutrients like; nitrogen $(\mathrm{N})$ which is an essential element that is increased in the presence of $\mathrm{Si}$. Nitrogen metabolism is a major factor in stem and leaf growth and too much can delay or prevent flowering. Pati et al., (2016) found that higher concentrations of soluble $\mathrm{Si}$ enhanced the uptake and concentration of $\mathrm{N}$. Others have noted that $\mathrm{Si}$ has the potential to raise available $\mathrm{N}$ and $\mathrm{N}$-use efficiency in plants (Savant et al., 1996 and Singh, 2005). The findings of the present investigation of number of days to flowering are in close conformity with Whitted-Haag et al., (2014) on Impatiens walleriana, Helaly and El-Hoseiny (2017) on Banana (Musa cavendishii L.) and Shanan and El Sadek (2017) on tuberose.

The interaction effect between the application methods "spray or soil drench" and silicon levels on flower characteristics of $N$. tazetta plants were significant in both seasons (Table, 4). The combined treatment of soil drench and silicon at $7.5 \mathrm{mmol}$ recorded the highest mean values for flowering duration, flower diameter, flower longevity, flower number per plant, flower fresh weight, flower dry weight, scape length, scape fresh and dry weight compared to the control in both seasons. On the other hand, the longest mean value of number of days to flowering was achieved of the control treatment. The estimated percentages increase in flowering duration, flower diameter, flower longevity, flowers number per plant, flower fresh weight, flower dry weight, scape length, scape fresh and dry weight were (37.72 and $34.17 \%)$, (40.77 and $36.74 \%)$, (71.94 and $67.87 \%)$, (67.87 and $75.78 \%)$, (71.93 and $63.64 \%)$, (360and 175\%), (21.28and 27.52), (49.14and 47.55\%) and (73.40and $81.82 \%$ ) compared to the control treatment for the first and second season, respectively. The present results are in parallel with those reported by Ahmad et al. (2013), Gonzalez-Peres et al. (2014) and Khenizy and Ibrahim (2015) on gladiolus.

\section{Photosynthesis pigments:}

Regarding the main effect of application methods "spray or soil drench" onchlorophyll a, chlorophyll $\mathrm{b}$ and carotenoids, data in Table (5)that showed clearly that the differences between the two application methods were not significant.

Regarding the main effect of different rates of silicon on photosynthesis pigments content, data in Table (5) indicated that, as silicon levels increased the given photosynthesis pigments parameters i.e. chlorophyll a, chlorophyll b and carotenoids significantly increased in both seasons, while chlorophyll $\mathrm{b}$ and carotenoids in the first season were not affected compared to control treatment. Irrespective of chlorophyll a at $5 \mathrm{mmol} \mathrm{Si}$ in the second season, there were no significant differences between the two concentrations 5 and $7.5 \mathrm{mmol}$ of silicon in the other photosynthesis pigments characters in both seasons. 
Table 5: Effects of silicon concentrations and its application method onphotosynthesis pigments content in $N$. tazetta plants during both seasons.

\begin{tabular}{llcccccc}
\hline \multirow{2}{*}{ Treatments } & \multicolumn{2}{c}{ Chlorophyll A $(\boldsymbol{\mu g} / \mathbf{m L})$} & \multicolumn{2}{c}{ Chlorophyll B $(\boldsymbol{\mu g} / \mathbf{m L})$} & \multicolumn{2}{c}{ Carotenoids $(\boldsymbol{\mu g} / \mathbf{m L})$} \\
\cline { 2 - 7 } & \multicolumn{1}{c}{$\mathbf{1}^{\text {st }}$} & $\mathbf{2}^{\text {nd }}$ & $\mathbf{1}^{\text {st }}$ & $\mathbf{2}^{\text {nd }}$ & $\mathbf{1}^{\text {st }}$ & $\mathbf{2}^{\text {nd }}$ \\
\hline $\mathrm{S}$ & $13.08 \mathrm{~A}$ & $12.56 \mathrm{~A}$ & $6.70 \mathrm{~A}$ & $6.56 \mathrm{~A}$ & $3.66 \mathrm{~A}$ & $3.34 \mathrm{~A}$ \\
\hline $\mathrm{D}$ & & $13.88 \mathrm{~A}$ & $13.41 \mathrm{~A}$ & $6.70 \mathrm{~A}$ & $6.83 \mathrm{~A}$ & $3.53 \mathrm{~A}$ & $3.10 \mathrm{~A}$ \\
\hline & 0 & $12.11 \mathrm{~B}$ & $11.22 \mathrm{C}$ & $6.17 \mathrm{~A}$ & $5.42 \mathrm{~B}$ & $3.38 \mathrm{~A}$ & $2.90 \mathrm{~B}$ \\
& 5 & $13.81 \mathrm{~A}$ & $13.60 \mathrm{~B}$ & $6.91 \mathrm{~A}$ & $7.33 \mathrm{~A}$ & $3.65 \mathrm{~A}$ & $3.26 \mathrm{~A}$ \\
& 7.5 & $14.52 \mathrm{~A}$ & $14.14 \mathrm{~A}$ & $7.03 \mathrm{~A}$ & $7.34 \mathrm{~A}$ & $3.77 \mathrm{~A}$ & $3.50 \mathrm{~A}$ \\
\hline \multirow{2}{*}{} & 0 & $12.42 \mathrm{bc}$ & $11.43 \mathrm{bc}$ & $6.02 \mathrm{a}$ & $5.74 \mathrm{bc}$ & $3.23 \mathrm{a}$ & $2.86 \mathrm{a}$ \\
$\mathrm{S}$ & 5 & $13.11 \mathrm{bc}$ & $12.98 \mathrm{abc}$ & $7.06 \mathrm{a}$ & $7.03 \mathrm{ab}$ & $3.70 \mathrm{a}$ & $3.39 \mathrm{a}$ \\
& 7.5 & $13.72 \mathrm{abc}$ & $13.26 \mathrm{abc}$ & $7.03 \mathrm{a}$ & $6.92 \mathrm{abc}$ & $4.05 \mathrm{a}$ & $3.78 \mathrm{a}$ \\
\hline & 0 & $11.79 \mathrm{c}$ & $11.01 \mathrm{c}$ & $6.32 \mathrm{a}$ & $5.09 \mathrm{c}$ & $3.53 \mathrm{a}$ & $2.95 \mathrm{a}$ \\
$\mathrm{D}$ & 5 & $14.51 \mathrm{ab}$ & $14.22 \mathrm{ab}$ & $6.76 \mathrm{a}$ & $7.64 \mathrm{ab}$ & $3.59 \mathrm{a}$ & $3.14 \mathrm{a}$ \\
& 7.5 & $15.32 \mathrm{a}$ & $15.01 \mathrm{a}$ & $7.02 \mathrm{a}$ & $7.76 \mathrm{a}$ & $3.48 \mathrm{a}$ & $3.22 \mathrm{a}$ \\
\hline
\end{tabular}

$\overline{1^{\text {st }} \text { and } 2^{\text {nd }} \text {; first season and second season. Means were compared using Tukey's Honest Significant Difference test }}$ $(P \leq 0.05) ; \mathrm{n}=3$; Means with the same small letter show no significant interaction between different concentrations and application method of $\mathrm{Si}$ and means with the same capital letters are no significantly different between application methods.

The increases of photosynthesis pigments content due to silicon might be to the role of silicon in reducing activities of chlorophyll-degrading enzymes (guaiacol peroxidase and ascorbate peroxidase) which, accompanied by increasing the chlorophyll production in $\mathrm{Si}$ treated plants as compared to the control (Gong et al., 2005 and Soundararajan et al., 2014). Also, it might be to the main role of $\mathrm{Si}$ in increasing the chlorophyll content arises from its conservation of the chloroplast ultrastructure which in turn improving biosynthetic of chlorophyll enzymes or decreasing of chlorophyll-degrading enzymes (Sharifi-Rad et al., 2016).

These results seemed to agree with those reported by Soundararajan et al., (2014) on Salvia splendens 'VistaRed' and 'Sizzler Red'.

The interaction effects between application methods and concentrations of silicon on photosynthesis pigments of $\mathrm{N}$. tazetta plants are presented in Tables (5). The combined treatment of soil drench and silicon at $7.5 \mathrm{mmol}$ recorded, generally, the highest mean values of chlorophyll a, chlorophyll $\mathrm{b}$ and carotenoids of $N$. tazetta leaves in both seasons.

These results seemed to agree with those reported by Khenizy and Ibrahim (2015) on Gladiolus and Shanan and El Sadek (2017) on tuberose.

Silicon content in leaves, bulbs, and flowers ( $\mu$ g/g D.W):

Regarding the main effect of application methods "spray or soil drench" on silicon contents in leaves, bulbs and flowers, data in Table (6) displayed clearly that the application method of soil drench exposed significant difference and gave the highest mean values of silicon contents of bulbs and flowers, however, silicon content in leaves was not affected in both seasons compared to spray method. The present results are in agreement with those obtained by several authors; Soundararajan et al., (2014) on Salvia splendens 'VistaRed' and 'Sizzler Red', Jayawardana et al., (2014) on Capsicum and Kamenidou et al., (2008) on Helianthus annuus.

Relating to the main effect of different levels of silicon on silicon contents in leaves, bulbs and flowers data in Table (6) indicated that, as silicon levels increased the silicon contents in leaves, bulbs and flowers significantly increased in both seasons compared to control treatment. Results, also, showed that silicon level at $7.5 \mathrm{mmol}$ recorded the highest mean values for the above-mentioned silicon characters in both seasons. This might be due to the increase in root growth and enhanced soil silicon availability with silicon application. This finding is in agreement with those reported by Kalyan et al. (2006) and Khalifa et al. (2016) also, this could be due to increased root activity and enhanced the soil nutrient availability in accordance with those reported by Wani et al. (2000). The obtained results seemed to agree with those reported by Jayawardana et al., (2014) on Capsicum, Soundararajan et al., (2014) on Salvia splendens and Babalar et al., (2016) on Gerbera jamesonii.

The interaction effects between application methods and silicon concentrations in different plant parts are presented in Tables (6). The combined treatment of soil drench and $7.5 \mathrm{mmol}$ recorded the highest mean values of silicon content in leaves, bulbs, and flowers in $N$. tazetta plant in both seasons. the estimated percentages increase in Silicon content in leaves, bulbs, and flowers were (45.51 and $49.64 \%$ ), (41.96 and $46.28 \%$ ), and (90 and $53.47 \%$ ) compared to the control treatment and for the first and second season, respectively. 
Table 6: Effects of silicon concentrations (Si) and its application method onSi content in leaves, bulbs, and flowers in $\mathrm{N}$. tazetta plants during both seasons.

\begin{tabular}{llcccccc}
\hline & Treatments & \multicolumn{2}{c}{$\begin{array}{c}\text { Si content in leaves } \\
(\boldsymbol{\mu g} / \mathbf{g})\end{array}$} & $\begin{array}{c}\text { Si content in bulbs } \\
(\boldsymbol{\mu} \mathbf{g} / \mathbf{g})\end{array}$ & \multicolumn{2}{c}{$\begin{array}{c}\text { Si content in flowers } \\
(\boldsymbol{\mu g} / \mathbf{g})\end{array}$} \\
\cline { 2 - 8 } & & $\mathbf{1}^{\text {st }}$ & $\mathbf{2}^{\text {nd }}$ & $\mathbf{1}^{\text {st }}$ & $\mathbf{2}^{\text {nd }}$ & $\mathbf{1}^{\text {st }}$ & $\mathbf{2}^{\text {nd }}$ \\
\hline $\mathrm{S}$ & & $4939.89 \mathrm{~A}$ & $4929.04 \mathrm{~A}$ & $5522.64 \mathrm{~B}$ & $5487.86 \mathrm{~B}$ & $3575.21 \mathrm{~B}$ & $4102.72 \mathrm{~B}$ \\
\hline $\mathrm{D}$ & & $4950.20 \mathrm{~A}$ & $4991.44 \mathrm{~A}$ & $6014.93 \mathrm{~A}$ & $6032.01 \mathrm{~A}$ & $4401.39 \mathrm{~A}$ & $4363.36 \mathrm{~A}$ \\
\hline & 0 & $4059.67 \mathrm{C}$ & $4064.50 \mathrm{C}$ & $4902.76 \mathrm{C}$ & $4875.75 \mathrm{C}$ & $2627.22 \mathrm{C}$ & $3359.24 \mathrm{C}$ \\
& 5 & $4868.35 \mathrm{~B}$ & $4734.13 \mathrm{~B}$ & $5443.72 \mathrm{~B}$ & $5272.03 \mathrm{~B}$ & $4346.19 \mathrm{~B}$ & $4184.64 \mathrm{~B}$ \\
& 7.5 & $5907.13 \mathrm{~A}$ & $6082.09 \mathrm{~A}$ & $6959.89 \mathrm{~A}$ & $7132.03 \mathrm{~A}$ & $4991.5 \mathrm{~A}$ & $5155.25 \mathrm{~A}$ \\
\hline & 0 & $4087.33 \mathrm{~d}$ & $4090.00 \mathrm{c}$ & $4723.74 \mathrm{e}$ & $4693.84 \mathrm{e}$ & $1743.04 \mathrm{e}$ & $3229.56 \mathrm{e}$ \\
$\mathrm{S}$ & 5 & $4939.44 \mathrm{c}$ & $4642.25 \mathrm{~b}$ & $5157.7 \mathrm{~d}$ & $4812.33 \mathrm{e}$ & $3992.93 \mathrm{c}$ & $4003.81 \mathrm{c}$ \\
& 7.5 & $5792.90 \mathrm{~b}$ & $6054.86 \mathrm{a}$ & $6686.49 \mathrm{~b}$ & $6957.4 \mathrm{~b}$ & $4989.67 \mathrm{a}$ & $5074.8 \mathrm{a}$ \\
\hline & 0 & $4032.00 \mathrm{~d}$ & $4039.00 \mathrm{c}$ & $5081.78 \mathrm{~d}$ & $5057.66 \mathrm{~d}$ & $3511.4 \mathrm{~d}$ & $3488.94 \mathrm{~d}$ \\
$\mathrm{D}$ & 5 & $4797.25 \mathrm{c}$ & $4826.02 \mathrm{~b}$ & $5729.74 \mathrm{c}$ & $5731.73 \mathrm{c}$ & $4699.45 \mathrm{~b}$ & $4365.48 \mathrm{~b}$ \\
& 7.5 & $6021.35 \mathrm{a}$ & $6109.31 \mathrm{a}$ & $7233.28 \mathrm{a}$ & $7306.65 \mathrm{a}$ & $4993.33 \mathrm{a}$ & $5235.69 \mathrm{a}$ \\
\hline
\end{tabular}

$1^{\text {st }}$ and $2^{\text {nd }}$; first season and second season. Means were compared using Tukey's Honest Significant Difference test $(P \leq$ $0.05) ; \mathrm{n}=3$; Means with the same small letter show no significant interaction between different concentrations and application method of Si and means with the same capital letters are no significantly different between application methods.

\section{CONCLUSIONS}

Results of current study reported that most of shoot, root, bulbs, and flower characteristics were improved. Therefore, this study provided a piece of evidence about the possibility of using silicon, especially at $7.5 \mathrm{mmol}$ ) as soil drenche for enhancinggrowth, yield, and quality of $N$. tazetta plants.

\section{ACKNOWLEDGMENTS}

The authors would like to sincerely thank Prof. Dr. Said Gaber, Emeritus Professor of Horticulture, Faculty of Agriculture, Damanhour University and Prof. Dr. Bassiouny Abdel-Maksoud AbdelMaksoud, Emeritus Prof. of Floriculture, Ornamental Horticulture and Landscape Gardening, Faculty of Agriculture, Alexandria University for revising the manuscript.

\section{REFERENCES}

Aghajani, M. and Jafarpour. M. 2016. Effects of Pre- and Postharvest Treatments of Silicon and Rice Hull Ash on Vase Life of Gerbera. International Journal of Horticultural Science and Technology. 3(1): pp 77-87.

Ahmad, A.,Afzal, M., Ahmad,A. U. H. and Tahir,M. 2013. Effect of foliar application of silicon on yield and quality of rice (Oryza sativa). cercetări agronomice în moldova. vol. xlvi, No. 3 (155).

Amin, M.; Ahmad, R., Ali, A., Hussain, I., Mahmood, R., Aslam, M. and Lee, D. J. 2016. Influence of silicon fertilization on maize performance under limited water supply. 10, 177-183. [CrossRef].
AOAC.2000. Volume of Packed Nuts. AOAC Official Method No 971.25.

Babalar, M.; Edrisi, B. and Naderi, R. 2016. Evaluation of the mechanical strength of gerbera flower stem in response to silicon and salicylic acid application. J. Ornamen. Plants, 6 (3), 163-171.

Bayat, H. and Aminifard, M. H. 2018. Effects of Different Preservative Solutions on Vase Life of Narcissus tazetta Cut Flowers. Journal of Ornamental Plants, 8(1): 13-21.

Bazaraa, W.M. 2018. Improving the growth, flowering and corm production of Freesia refracta $\mathrm{cv}$. Red Lion by using some growing media and fertilization treatments. Middle East J. Agric. Res., 7(4): 1381-1394. ISSN: $2077-$ 4605.

Benschop, M., le Nard, M., Okubo, H. and de Hertogh, A. 2010. The global flower bulb industry: Production, utilization, research. Hort. Rev. 36:1-115.

Black, C.A., Evans,D. D. and Dinauer, R.C. 1965. Methods of soil analysis. Madison, WI: Amer. Soc. of Agron., 9: 653-708.

Carvalho, P. R. 2013. Efeito do silício na qualidade de flores de Dendrobium nobile (Orchidaceae). Semina: Ciências Agrárias. 34(4):1615-1622.

Carvalho-Zanão, M. P., Villa, F. and Júnior, L. A. Z. 2017. Gladiolus production and nutritional status as a function of silicon application to the substrate. Pesq. Agropec. Trop., Goiânia. 47(2); 178-185. 
Chen, H. C., Chi, H. S. and Lin, L. Y. 2013. Headspace solid-phase micro extraction analysis of volatile components in Narcissus tazetta var. 'Chinensis Roem'. Molecules, 18: 13723- 13734.

CoStat. 2008. CoStat program, version 6.4. CoHort Software, Monterey, CA., USA

Dole, J. M. and Wilkins, H. F. 2005. Floriculture principles and species. Prentice-Hall Inc. New Jersey. $613 p$.

Elliott, C. L; Snyder, G. H. 1991. Autoclaveinduced digestion for the colorimetric determination of silicon in rice straw. Journal of Agricultural and Food Chemistry, 39: 11181119.

Epstein, E. 1999. Silicon. Annu. Rev. Plant Physiol. Plant Mol. Biol. 50: 641-664

Epstein, E. 1994. The anomaly of silicon in plant biology. Proc. Natl. Acad. Sci. USA 91: 1117.

Gao, X., Zou, C., Wang, L. and Zhang,F. 2006. Silicon decreases transpiration rate and conductance from stomata of maize plant. J. Plant Nutr., 29: 1637-1647.

Gong, H.J., Zhu,X.Y. and Chen, K.M. (2005). Silicon alleviates oxidative damage of wheat plants in pots under drought. Plant Sci., 169, 313-321.

Gonzalez-Peres, E., Ayala-Garay, O. J. and YanezMorales, M. J. 2014. Indications that some nutritional elements can improve gladiolus corm and cormel qualities in Mexico. Chilean J. Agric. Res., 74 (1), 9-18.

Hanks, G. R. 1993. Narcissus. p. 463-558. In: A. De Herthogh and M. Le Nard (eds.), The Physiology of Flower Bulb, Elsevier, Amsterdam.

Hanks, G. R. 2002. Commercial production of Narcissus, p. 53-130. In: Hanks, G.R. (ed.). Narcissus and daffodil. The genus Narcissus. Taylor and Francis, London.

Helaly, M. N. and El-Hosieny, H. A. R. 2017. Effects of Silicon and Yeast Extract on Growth, Flowering and Yield of Banana (Musa cavendishii L.). J. Plant Production, Mansoura Univ., Vol. 8 (4): 549 - 554.

Hodson, M. J. and Sangster, A. G. 1999. Aluminum/silicon interactions in conifers. Journal of inorganic biochemistry. Vol. 76 (2), pp. 89-98.

Hossain, M. T., Mori, R., Soga, K., Wakabayashi, K., Kamisaka, S., Fujii, S. and Hoson, T. (2002). Growth promotion and an increase in cell wall extensibility by silicon in rice and some other Poaceae seedlings. Journal of Plant Research, 115(1), 23-27.
Isa, M., Bai, S., Yokoyama, T., Ma, J. F., Ishibashi, Y., Yuasa, T. and Iwaya-Inoue, M. (2010). Silicon enhances growth independent of silica deposition in a low-silica rice mutant, 1si1. Plant and Soil, 331(1-2), 361-375.

Jana, S. and Jeong, B. R. 2014. Silicon: the most underappreciated element in horticultural crops. Trends in Horticultural Research, 4(1): p. $1-19$

Janmohammadi, M., Mohammadi, N., Shekari, F., Abbasi, A. and Esmailpour, M. 2017. The effects of silicon and titanium on safflower (Carthamus tinctorius L.) growth under moisture deficit condition. Acta Agriculturae Slovenica, 109(2): 443-445.

Jayawardana, H. A. R. K., Weerahewa, H.L.D. and Saparamadu, M. D. J. S. 2014. Effect of root or foliar application of soluble silicon on plant growth, fruit quality and anthracnose development of Capsicum. Tropical Agricultural Research. 26 (1): $74-81$.

Kalyan, S., Singh, R., Singh, J.P., Singh,Y.and Singh,K. K. 2006. Effect of level and time of Silicon application on growth, yield and its uptake by rice (Oryza sativa). Indian J. Agric. Sci. 76(7): 410 - 413.

Kamenidou, S., Cavins, T. J. and Marek, S. 2008. Silicon supplements affect horticultural traits of greenhouse-produced ornamental sunflowers. HortScience 43:236-239.

Kamenidou, S., Cavins, T. J. and Marek, S. 2009. Evaluation of silicon as a nutritional supplement for greenhouse zinnia production. Scientia Hort. 119(3): 297-301.

Khalifa, A., Hussein,M. A. and Goma, M. A. 2016. Effect of sulphur and silicon application on the yield and chemical composition of maize grown under saline soil conditions. J. Adv. Agric. Res. (Fac. Agric. Saba Basha). 21(3); 496-509.

Khenizy, S. A. M. and H. E. Ibrahim. 2015. Effect of Silicon and/ or NPK Treatments on Growth, Flowering and Corm Production in Gladiolus. Egypt. J. Hort. Vol. 42, No. 2, pp. 839 - 851.

Korndörfer, G. H., Pereira, H. S. and Nolla, A. 2004. Silicon analysis in soil, plant and fertilizers. Brazil, GPSi/ICIAG/UFU.

Le, V.N.,Rui, Y., Gui, X.,Li, X., Liu, S. and Han, Y. 2014. Uptake, transport, distribution and bioeffects of $\mathrm{SiO} 2$ nanoparticles in Bttransgenic cotton. Journal of Nanobiotechnology, 12(1): 50- 59.

Liang, Y. C., Chen, Q., Liu,Q., Zhang, W. H. and Ding, R. X. 2003. Exogenous silicon (Si) increases antioxidant enzyme activity and reduces lipid peroxidation in root of saltstressed barley (Hordium vulgare L.). Journal of Plant Physiology 160: 11571164. 
Liang, Y., Yang, C. and Shi, H. 2001. Effects of silicon on growth and mineral composition of barley grown under toxic levels of aluminum. Journal of Plant Nutrition. 24(2), pp. 229-243.

Liang, Y., Wanchun, S., Yong-Guan, Z. and Peter, C. 2006. Mechanisms of silicon-mediated alleviation of abiotic stresses in higher plants: A review. Environ Pollut. 1: 01-07.

Lichtenthaler, H. K. and Buschmann. C. 2001. chlorophylls and carotenoids: measurement and characterization by UV-VIS spectroscopy," in Current Protocols in Food Analytical Chemistry, John Wiley \& Sons, New York, NY, USA, pp. F4.3.1-F4.3.8.

Lindsay, W.L.1979. Chemical equilibrium in soil. John Wiley \& Sons. New York.

Lu, C. M., Zhang, C.Y., Wen, J.Q., Wu, G. R. and Tao, M. X. 2002. Research on the effect of nanometer materials on germination and growth enhancement of Glycine max and its mechanism. Soybean Science, 21: 68-172.

$\mathrm{Lu}, \mathrm{G}$. and Cao, J. 2001. Effects of silicon on earliness and photosynthetic characteristics ofmelon. Acta Horticulturae Sinica. 28: 421424.

Ma, J. F. and Takahashi, E. 2002. Soil, Fertilizer, and Plant Silicon Research in Japan. 1st ed., Elsevier Science, p: 294.

Ma, J. F. and Yamaji, N. 2006. Silicon uptake and accumulation in higher plants. Trends in Plant Science, 11(8), 392-397.

McAvoy, R. J. and Bernard, B. B. 1996. Silica sprays reduce the incidence and severity of bract necrosis in poinsettia. HortScience 31: 1146- 1149.

Mirabbasi, N., Nikbakht, A., Etemadi,N. and Sabzalian, M.R. 2013. Effect of different concentrations of potassium silicate, nanosilicon and calcium chloride on concentration of potassium, calcium and magnesium, chlorophyll content and number of florets of Asiatic lily cv. 'Brunello'. J. Sci. \& Technol. Greenhouse Culture, 4: 14.

Novozamsky, I., van Eck, R. and Houba, V. J. B. 1984. A rapid determination of silicon in plant material. Communications in Soil Science and Plant Analysis 15: 205-211.

Pati, S., Pal. B., Badole. S., Hazra. G.C. and Mandal, B. 2016. Effect of silicon fertilization on growth, yield, and nutrient uptake of rice. Commun. Soil Sci. Plant Anal. 47(3): 284-290.

Romero-Aranda, M. R, Jurado, O. and Cuartero, J. 2006. Silicon alleviates the deleterious salt effect on tomato plant grow by improving plant water status. Journal of Plant Physiology 163: 847855 .
Roohizadeh, G., Majd, A. And Arbabian, S. 2015. The effect of sodium silicate and silica nanoparticles on seed germination and some of growth indices in the Vicia faba L. Tropical Plant Research. 2(2): 85-89.

Rubinowska, K., Pogroszewska, E., Laskowska, H., Szot, P., Zdybel, A., Stasiak, A. and Kozak, D. 2014. The subsequent effect of silicon on physiological and biochemical parameters of Polygonatum multiflorum (L.)All. 'Variegatum' cut shoots. Acta Sci. Pol. Hortorum Cultus, 13(1): 167-178.

Santos-Gally, R., Vargas, P. and Arroyo, J. 2011. Insights into Neogene Mediterraneanbiogeography based on phylogenetic relationships of mountain and lowland lineages of Narcissus (Amaryllidaceae). J. Biogeogr. 39:782-798.

Savant, N. K., Snyder, G. H. and Datnoff, L. E. 1996. Silicon management and sustainable rice production. Adv. Agron. 58: 151-199.

Seebold, K. W., Kucharek, T. A., Datnoff, L. E., Correa-Victoria, F. J. and Marchetti, M. A. 2001. The influence of silicon on components of resistance to blast in susceptible, partially resistant, and resistant cultivars of rice. Phytopathology. 91(1): 63-69.

Shanan, N. T. and El Sadek, Z. H. 2017. Influence of Silicon on Tuberose Plants under Drought Conditions. Middle East Journal of Agriculture Research. 06 (02): 348-360. ISSN 2077-4605.

Sharifi-Rad, J., Sharifi-Rad, M. and Teixeira da Silva, J. A. 2016. Morphological, physiological and biochemical responses of crops (Zea mays L., Phaseolus vulgaris L.), medicinal plants (Hyssopus officinalis L., Nigella sativa L.), and weeds (Amaranthus retroflexus L., Taraxacum officinale F. $\mathrm{H}$. Wigg) exposed to $\mathrm{SiO}_{2}$ nanoparticles. J. Agr. Sci. Tech., 18: 1027-1040.

Singh, A. K., Singh, R. and Singh, K. 2005. Growth, yield, and economics of rice (Oryza sativa) as influenced by level and time of silicon application. Ind. J. Agron. 50: 190-93.

Sivanesan, I. and Park, S. 2014. The role of silicon in plant tissue culture. Frontiers in Plant Sci., 5 (5), 1 - 4.

Snedecor, G.W and Corchan, W.G. 1967. Statistical Methods. 6th Edition. Iowa State Univ. Press, Ames, Iowa, U.S.A.

Sochacki, D. and Orlikowska, T. 2005. The obtaining of Narcissus plants free from potyviruses via adventitious shoot regeneration in vitro from infected bulbs. Sci. Hortic., 103: 219-225. 
Soundararajan, P., Sivanesan, I., Jana, S. and Jeong, B. R. 2014. Influence of silicon supplementation on the growth and tolerance to high temperature in Salvia splendens. Hort. Environ. And Biotechnol., 55: 271-279.

Steininger, J. 2010. The lowdown on daffodils. Greenhouse Grower March:52-55.

Taber, H. G., Shogren, D. And Lu, G. 2002. Extraction of silicon from plant tissue with dilute HCL and HF and measurement by modified inductive coupled argon plasma procedures. Commun. Soil Sci. Plant Anal. 33(9\&10): $1661-1670$.

Tamai, K., and Ma, J. F. 2008. Reexamination of silicon effects on rice growth and production under field conditions using a low silicon mutant. Plant and Soil, 307(1-2), 21-27.

Van Dort, H. M., Jagers, P. P., ter Heide, R. and van der Weerdt, A. J. A. 1993. Narcissus trevithian and Narcissus geranium. Analysis and synthesis of compounds. Journal of Agricultural and Food Chemistry, 41: 20632075.

Wani, M.A., Refique,M. M. and Talib,A. R. 2000. Effect of different levels of sulphur orn quality of rice. Adv. plant Sci., 13(1): 55-57.

Wedepohl, K. H. 1995. The composition of the continental crust. Geochim Cosmochim Ac. 7: 1217-1232.

Whitted-Haag, B., Kopsell, D.E., Kopsell, D.A. and. Rhykerd, R.L. 2014. Foliar silicon and titanium applications influence growth and quality characteristics of annual bedding plants. Open Hort. J. 7: 6-15.
Wróblewska, K. and Dębicz, R. 2011. The effect of silicon foliar application on the development of season ornamental plants. Part II: Argyranthemum frutescens'Blazer Rose', Xerochrysum bracteatum 'Gold', Osteospermum ecklonis 'Grande Pink Bush' and Gauralindheimeri 'Corinas Choice'. Acta Agro bot., 64(4): 107-114.

Zaky, A. A. 2013. Effect of pre- and postharvest treatments on flower longevity of cut rose cv. 'grand prix'. egypt. j. agric. res., 91(3).

Zaky, A. A. 2014. Effect of fertilization and garlic extract on growth, quality and flowering of Zantedeschia aethiopica cv. Eleganza. J. Biol. Chem. Environ. Sci., 9 (1), 15-32.

Zhao, D., Hao, Z., Tao, J. and Han,C. 2013. Silicon application enhances the mechanical strength of inflorescence stem in herbaceous peony (Paeonia lactiflora Pall.). Scie. Hort., 151: 165-172.

Zhou, Q., Pan, G., Shi, Z., Meng, Y. and Xie, Y. 2002. Effects of $\mathrm{Si}$ fertilizer application on maize yield and on quality of maize population. J. of Maize Sci. 10(1): 81-93.

Zidan, E. 1962. Evaluation of some Tomato lines in regard to leaf area efficiency and relation of partial defoliation to early and total yield fruit size, soluble solids, leaf rolling and blossom and rot. Ph. D. Thesis, Cornell Univ. Ithaca. New York, U.S.A. 


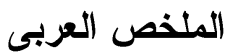

\section{تأثير استخدام مستويات مختلفة من عنصر السيلكون وطريقة التطبيق على معدلات النمو}

Narcissus tazetta L. وخصائص الجوده لنبات النرجس

زامي جابر الكناني'، عاطف محمد خضر نصار ' 'البن

'قنسم البساتين

كسم وقاية النبات

كلية الزر اعة -جامعة دمنهور - دمنهور - محافظة البحيرة - جمهورية مصر العربية

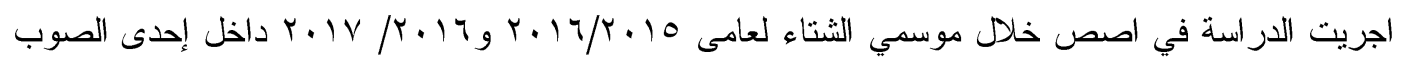

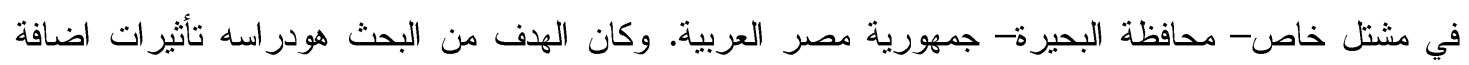

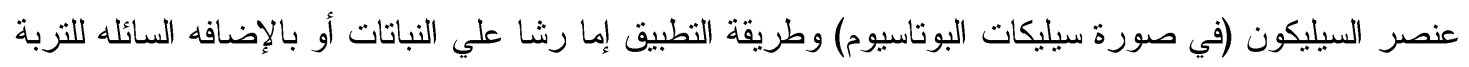

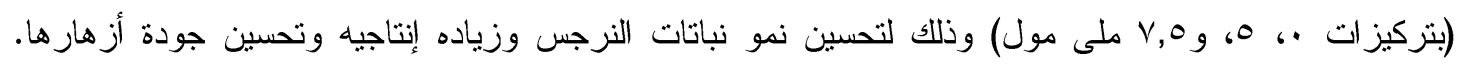
صممت الدراسة باستحدام تصميم القطاعات المنشقه داخل نظام القطاعات كامله العشوائية. وقد أظهرت ودئ النتائج

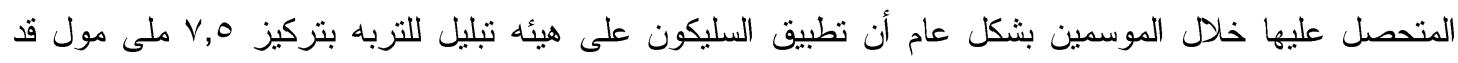

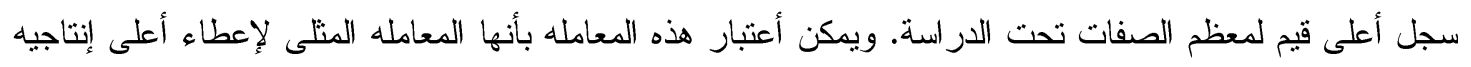
و أفضل جوده لنباتات النرجس وذلك تحت الظروف البيئيه لمحافظه البحيره أو المناطق الأخرى المماثله لها. 